\title{
Government Spending, Corruption and Output Growth in Nigeria
}

\section{Ogunlana Olarewaju $F$}

Department of Economics, Faculty of Social Sciences, Lagos State University, Lagos, Nigeria

doi: 10.19044/esj.2016.v12n16p291 URL:http://dx.doi.org/10.19044/esj.2016.v12n16p291

\begin{abstract}
This study used the works of Barro(1990), Bakare(2011), and Dissou and Yakautsava (2011) to establish the relationship between government spending, corruption and output growth in Nigeria. It employed aggregated data from 1980 to 2011. Using the Johansen Maximum Likelihood procedure and error correction mechanism, the study showed that the estimates of money supply, capital formation, openness to trade and innovation system positively influenced output growth while unemployment and domestic debt affected output negatively. Public investment as a percentage of GDP and corruption influenced adversely output growth. The paper recommends that corruption tilts public spending away from growth enhancing projects and towards low and less productive ones.
\end{abstract}

Keywords: Corruption, growth, investment, public spending

\section{Introduction}

The involvement of government in the economy rests on three major roles namely: allocative, stabilization and distributive. The state is also saddled with the responsibility of making available certain goods and public services to every member of the society. The existence of corruption in any economic system may prevent government from fulfilling its roles as expected. Empirical studies on corruption are well documented in the literature. In particular, a number of empirical analyses on corruption have explored Barro (1991) and Levine and Renelt (1992) ${ }^{10}$ specifications. There are two branches of corruption thoughts in the literature. A branch of study suggests that corruption serves as stimulant which drives economic growth thereby providing an easy route for individuals to get things done by circumventing bureaucratic processes. Advocates of this view feels that

10 These approaches have regressed cross-sectional estimates of corruption on the average rate of economic growth and a set of control variables. 
when bribes are given to individuals, it would motivate the speed of job turnover faster than expected (See the works of Leff, 1964; Huntington, 1968; Acemoglou and Verdier, 1998 for details). The other branch of corruption study posits that corruption exerted negative effects on long run growth path through its impact on the quality of infrastructures, governance, government expenditure, resource allocation and welfare (Aidt, 2003; Svensson, 2005).

The author is very mindful of the fact that there are many ways in which corruption could impede economic growth. Apart from the work by Mauro(1995) which underscores the effect of corruption on growth through investment channel, Pellegrini and Gerlaugh(2004) approached the theme "corruption and economic growth" by establishing an indirect relationship route through human capital, political/economic stability and degree of trade openness. The literature evidence has shown that corruption rendered the efficacy of tax collection useless, skewed the composition of government expenditure away from growth enhancing projects towards less productive ones. In line with this, Rose-Ackerman (1999) noted that corrupt bureaucrats tends to commit scarce economic resources to the type of expenditure that favours bribes accumulation. However, Shleifer and Vishny (1993) identified the examples of public expenditure that favours corruption. They observed that expenditures in military equipments and large infrastructural projects are conduit pipe where state resources are squandered. Along the same line of reasoning, Mauro(1997), Gupta et.al.(2001), Tanzi, (1998), De La Croix and Delavallade (2007) argued that bribes could be easily be extracted from expenditure which involves high military defence armaments and infrastructure project such as hospital building, whose exact value and costs could not be easily ascertained than expenditures on teacher's salary.

Manifestation of corruption in public spending comes in the form of project execution, procurement of goods and services, extra budgetary spending, payments of salaries/wage to people who are not in employment contract, payments to dead pensioners, etc. The critical and fundamental question that needs to be addressed centres on the issue of transparency and institutional coherence within the system. Addressing this issue could foster good governance devoid of corrupt practices. Corruption is more visible and sustainable in an economy when public officers and representative of the citizens in government who were saddled with the responsibility of managing public resources perverted it for personal enhancement to the disadvantage of the society at large.

The model employed in this study is based on asymmetric information on the part of government and its agents which created a gap in information flow regarding the behaviour of the agents in terms of the provision of goods and services. Corruption cases in the public sector are similar to what is described in the principal-agent problem. The principal in 
this case is the government. The government assigns responsibilities and duties to the agents. Along the line of execution, the agents perverted public responsibilities for personal gains. Bardhan (1997) and Azariadis and Lahiri (1997) explored similar explanations to analyze the behaviour of government agents in relation to the provision of public infrastructures. This study used an econometric techniques to analyze the effect of corruption on the efficiency of public expenditure and how it impacted on growth in Nigeria. A Barro (1990) type endogenous growth model provided the bedrock of explaining the nexus of public spending, corruption and economic growth. Mauro (1997) and De La Croix and Doepke(2009) used similar model to analyze the relationship between corruption and growth. Apart from the introduction, section 2 contains the stylized facts and review of literature, section 3 presents the theoretical framework and methodology, while section 4 analyses the estimation techniques. Section 5 presents the empirical results while section 6 gives the concluding remarks.

\section{Stylized Facts and Review of Related Literature Corruption in Nigeria: The Evidence}

The definition given by the World Bank relates corruption to betrayal, misrepresentation on the part of public officers in the course of discharging the duties assigned to them to gain undue pecuniary benefits has attracted significant attention to the study of corruption in Nigeria. Accordingly, studies are inundated on the relationship between corruption and public spending both in the developed and developing economies. However, literatures converged in opinion ${ }^{11}$ on the effect of corruption on public spending and the consequential effects on economic growth.

${ }^{11}$. For more discussion on the impact of corruption on public spending, see the works of Mauro (1995), Pellegrini and Gerlagh (2004), Rose-Ackerman (1999) and Shleifer and Vishney (1993). Tax distortions and misallocation of government expenditure featured as critical channels through which corruption impacted on growth in developing economy.

3. The succession of dictatorial regimes, disregard of human rights, political instability and economic mismanagement have all contributed to cast Nigeria in a bad light internationally. These factors have also served to undermine Nigeria's economic growth and development potential, in terms of global development indicators. With a per capita income of $\$ 1,149$, Nigeria ranks amongst the least developed countries in the World Bank league tables ( See Salisu, 2000). Governors of various states appropriate public funds and allowances (e.g. monthly $\$ 5$ million as wardrobe allowance) to themselves which provide ample avenue for active money laundering. Some of these state governors have been found in law court to have committed electoral fraud and were consequently removed from office but without any confiscation of their properties or refund of the ill-gotten wealth. The senators appropriate huge money to themselves, continuously review upward their salaries and allowances, and belong to several sub-committee of the senate on one socio-economic issue or the other which serves as channels for wasting public funds in terms of over-bloated and spurious sitting allowances, claims and budgets. 
According to Human Rights Watch Report (2008), during the oil boom period, Nigeria made headlines with its oil resources, capable of financing a number of important projects to meet basic consumption and development needs. However, these resources are not channelled to the areas that are useful for the growth of the economy ${ }^{3}$. Beside this, corruption became a salient feature of the Nigerian economy particularly in the procurement of contracts and in the regulation of the economy and official business in general (Whitaker,1991). Most government decisions including legislative bills and litigation were driven by financial considerations.

Despite the huge oil revenue, Africa Confidential, 1999 report revealed that about 70 per cent of the population wallows in abject poverty and despair. The windfall gain from oil has not reflected in the overall living standard of the population. Today across Nigeria, public services have deteriorated sharply with bourgeoning poverty level. Ethnic diversity and parochial political interest among the ethnic tribes have further threatened the stability of the economy. With the emergence of democratic rule in Nigeria in 1999, this trend has not been reversed. The discovery of oil has been a blessing and a curse to Nigeria. It is a blessing because the oil wealth provided Nigeria with an easy entry into international capital markets. It also allowed the country to embark on large-scale public and private sector projects. The oil revenue has also introduced opportunities for rent-seeking behaviour and corrupt practices in both public and private sectors of the economy.

Corruption was reported as one of the problems confronting Nigeria's economic, political and social stability. It ranges from petty corruption to political or systemic corruption. Studies conducted by the World Bank (2007) have shown that corruption constituted a major factor which decimated the growth of GDP in countries like Nigeria, Kenya and Venezuela. However, it has been widely reported in the literature that corruption is harmful and detrimental to sustainable growth and development (Tanzi, 2002; Svensson, 2005; Gyimah-Brempong, 2002). The rate at which corruption is growing in the developed and developing countries sensitized the consciousness of the German-based non-governmental organization Transparency International (TI) to embark on a survey of corruption in countries where it is prevalent. A total number of 85 countries was surveyed in 1997 and Nigeria ranked 81st position. This implies that Nigeria ranked as the 5th most corrupt country in 1997. Similarly, the surveys of 1998, 2000 and 2001 further ranked Nigeria as the 2nd most corrupt nations in the world. The 2005 survey was carried out on 163 countries and Nigeria ranked in the 142nd position. This implies that Nigeria ranked 22nd most corrupt nation during the study period. Table 1 provided the detail ranking of Nigeria on the Transparency International's corruption index during the period 1998 
to 2011. Until June 2007, Nigeria has not been exonerated from the list of the top leading countries on corruption. In its 2012 report, Nigeria scored 27 out of a maximum 100 marks to occupy the 139th place out of the 176 countries surveyed in the report. With the latest ranking, Nigeria moved up four places from its ranking of 143 out of the 183 nations surveyed by TI in 2011. The country was ranked 134 out of 178 surveyed nations in 2010; 130 out of 180 nations in 2009; 121 out of 180 in 2008; Table 1 below summarises Nigeria's ranking for the fourteen-year period (1998-2011).

Table 1: Fourteen-Year Ranks of Nigeria on Transparency International's Corruption

Perception Index (1998-2011)

\begin{tabular}{|c|c|c|c|}
\hline Year* & CPI** & Rank*** & Position from Bottom**** \\
\hline 1998 & 1.2 & $81 / 85$ & $5^{\text {th }}$ \\
\hline 1999 & 1.6 & $98 / 99$ & $2^{\text {nd }}$ \\
\hline 2000 & 1.2 & $90 / 90$ & $1^{\text {st }}$ \\
\hline 2001 & 1.0 & $90 / 91$ & $2^{\text {nd }}$ \\
\hline 2002 & 1.6 & $101 / 102$ & $2^{\text {nd }}$ \\
\hline 2003 & 1.6 & $132 / 133$ & $3^{\text {rd }}$ \\
\hline 2004 & 1.6 & $144 / 146$ & $6^{\text {th }}$ \\
\hline 2005 & 1.9 & $152 / 168$ & $22^{\text {nd }}$ \\
\hline 2006 & 2.2 & $142 / 163$ & $33^{\text {rd }}$ \\
\hline 2007 & 2.2 & $147 / 179$ & $60^{\text {th }}$ \\
\hline 2008 & 2.7 & $121 / 180$ & $51^{\text {st }}$ \\
\hline 2009 & 2.5 & $130 / 180$ & $45^{\text {th }}$ \\
\hline 2010 & 2.4 & $134 / 178$ & $39^{\text {th }}$ \\
\hline 2011 & 2.5 & $143 / 182$ & \\
\hline
\end{tabular}

Source: Transparency International. www.transparencyinternational.org

Notes: *Year of report. Data refers to the previous year during which the survey was conducted; ${ }^{* *} \mathrm{CPI}=$ corruption perception index; its value is between 0 (extreme corruption) and 10 (no corruption at all); *** Countries are ranked by their CPI scores. The numerator is the rank of Nigeria and the denominator is the number of countries surveyed. For instance, 81/85 means that Nigeria was ranked at the $81^{\text {st }}$ position out of 85 countries surveyed in 1997 (i.e. the year before 1998). In other words, Nigeria was ranked the $5^{\text {th }}$ most corrupt country in 1997; **** A lower position indicates worsening corruption while a higher position indicates improvement (reduced corruption) relative to other countries.

The corruption picture on Nigeria based on Transparency International scores and ranking fundamentally classified Nigeria as an underdeveloped country. The Nigeria Corruption Index (NCI) of 2005 and 2007 developed by CLEEN foundation have identified some key organizations found to be corrupt based on the survey administered. The percentage score on the table indicated the level of corruption assigned to each sector. From Table 2, the average score for the two periods indicated 
that the police force had the highest score of $98 \%$. It was followed by the Power Holding Company with 85\%. Immigration and Passport had 52\%, followed by Federal Road Safety and Local Government Authorities with 47\%. Independent National Electoral Commission, Federal Inland Revenue and Ministry of Health have 38\%, 36\%, 31\% respectively. Other organizations included in the survey are: ministry of Justice, Ports Authority, Nigerian National Petroleum Commission, the presidency and Federal Housing Authority with the following scores: 29\%, 29\%, 28\%, 27\% and $27 \%$, respectively. The table shows that almost all sectors in Nigeria are corrupt.

Table 2 : Average Ranking of Corrupt Organizations in Nigeria

\begin{tabular}{|c|c|c|c|}
\hline Organization & $\begin{array}{c}\text { Year 2005 } \\
\text { \% Score }\end{array}$ & $\begin{array}{c}\text { Year 2007 } \\
\text { \% Score }\end{array}$ & $\begin{array}{c}\text { Average } \\
\text { \% Score }\end{array}$ \\
\hline The Police & 96 & 99 & 98 \\
\hline Power Holding Company Nigeria (PHCN) & 83 & 87 & 85 \\
\hline Ministry of Education & 63 & 74 & 69 \\
\hline Custom and Excise Department & 65 & 61 & 63 \\
\hline Federal Road Safety Corp. (FRSC) & 42 & 51 & 47 \\
\hline Immigration/ Passport Office & 56 & 48 & 52 \\
\hline Joint Admissions and Matriculation Board & 41 & 47 & 44 \\
\hline Local Government Authorities & 47 & 46 & 47 \\
\hline Independent National Electoral Commission INEC) & - & 38 & 38 \\
\hline Health Ministry/ Primary Health/ Teaching Hospital & 36 & 36 & 36 \\
\hline Ministry of Justice & 30 & 32 & 31 \\
\hline The Presidency & 27 & 31 & 29 \\
\hline Nigeria National Petroleum Commission (NNPC) & 27 & 29 & 27 \\
\hline Federal Housing Authority & 26 & 28 & 28 \\
\hline Nigeria Ports Authority/ Nigeria Maritime Authority & 33 & 24 & 29 \\
\hline
\end{tabular}

Source: Nigeria Corruption Index (2007), CLEEN Foundation.

\section{Review of Related Literature}

There is a growing body of literature on corruption system. However, evidence on the effects of such system on economic performance is multidimensional and massive. Landmarks in the literature in this area include Mauro(1995,1997), Tanzi and Davoodi(1997),Rose-Ackerman(1999), Mo(2001), De La Croix and Delavallade(2007), d'Agostino et.al(2011), Dissou and Yakautsava(2011). Corruption is more pervasive in developing countries as it affects expenditure on public projects. A number of evidences have been provided in the literature on the impact of corruption on growth. Most importantly, Mauro(1997) documents that corruption tilts away public expenditure from growth enhancing projects towards less productivity ones. Similar to Mauro's view, Tanzi and Davoodi(1997) observed that corruption provided an easy route where public funds are freely expended on bribeseeking projects. The conclusion drawn from these studies are quite 
instructive and informative. If corruption persists in an economy, public funds would be misallocated and misdirected to growth retarding projects with consequential effects on the quality of public infrastructures.

Empirical studies have provided mixed results on the effects of government expenditure on economic growth. The empirical regularity in the literature pointed at the influence of corruption on the composition of government expenditure thereby perverting the expenditure efficiency towards enhancing growth-driven projects where the scope for corruption is restricted (Mauro 1995,1997; Brunetti,1997; Ehrlich and Lui, 1999; Li, Xu and Zou ,2000; Mo ,2001; Abed and Davoodi,2002). Tanzi and Davoodi (1997) provided evidence on the influence of corruption on public spending. It was observed that corruption provided opportunity for rent-seeking and misallocation of public spending. With the incentives to be gained from corruption, public officers often commit public funds to projects whose exact values are difficult to estimate. More so, the revenue accruable to the government from the project are cornered by the corrupt officers to meet personal needs. Examples of projects where the scope for corruption is high in Nigeria are: government spending on military equipments, large infrastructure projects on hospital facilities, education equipments, electricity projects, water projects etc.

A number studies have identified different channels in which corruption could affect growth. Ndikumana(2007) provided a detailed taxonomy of these channels and the policy implications on growth. Baliamoune-Lutz and Ndikumana (2007) used Arellano Bond GMM technique to analyze the impact of corruption on growth by exploring investment channel. Findings from this study shows that corruption reduces the efficiency of private investment and at the same time raises production costs. Some branch of studies has also linked corruption to government spending and economic growth using panel data. Findings from these studies show that corruption reduces government size and worsen the level of per capita income (Ehrlich and Lui,1999). Similar results were obtained by Mo (2000) and Mauro(1995).

\section{Theoretical Framework and Methodology}

In this section, the work of Dissou and Yakautsava (2011) serves as the building framework of our model. This model assumes that corruption decimated the value output and growth. The model is described as explained below:

\section{The Basic Model}

The model specified in this study comprised three economic agents: consumer, firm and government. The consumer is assumed to maximize its 
utility subject to a given constraints. Also, the consumer owns the representative firm. It therefore implies that any profit made by the firm is accruable to the consumer. The firm's production function is built around public and private capital as inputs. Consumer's disposable income is spent on consumption, while the surplus is channelled to investment. Government levy taxes on income with the objective of running a balanced budget. If government is committed to growth enhancing projects with sincerity of purpose, it implies that all revenue inflows in the form of taxes would be invested completely on public capital. However, if government is committed to corrupt projects, only a fraction of the revenue inflows from taxes would be used to finance public capital. The remaining fraction is consumed as bribe.

\section{The Consumer}

We assumed that the individuals in the economy lived infinitely and derives greater utility from consumption of goods and services. The utility function of the consumer is expressed as:

$$
u=\int_{0}^{\infty} e^{-\rho t}\left(\frac{c_{t}{ }^{1-\sigma}-1}{1-\sigma}\right) d t
$$

Where $\rho$ is time preference, $\sigma$ is elasticity of substitution and $C_{t}$ is consumption.

\section{The Firm}

Firm's production function is expressed in the form of Cobb-Douglas production function given as:

$$
Y_{t}=K_{t}^{1-\alpha} G_{t}^{\alpha}
$$

where $K_{t}$ and $G_{t}$ are factor inputs. The production function is homogeneous of degree1 and has diminishing marginal returns to factor inputs.

\section{The Government}

The government levy taxes on output with the goal of running a balanced budget:

$$
G_{t}=\tau Y_{t}, \quad 0<\tau<1
$$

Equation (3.3) shows that government spending cannot exceed revenue inflow from taxation. If government is seriously committed to growth enhancing projects, it would ensure that no part of the revenue inflows from tax are channelled to questionable and unproductive projects by the corrupt public officials. The assumption that is placed on this model is that the firm takes government action in regards to tax administration as given and exogenous, the production function can be rewritten by substituting equation 3.3 into equation 3.2, which gives: 


$$
Y_{t}=K_{t}^{1-\alpha}\left(\tau Y_{t}\right)^{\alpha}
$$
now becomes:

Solving and expressing $Y_{t}$ as the subject, the production function

$$
Y_{t}=\tau^{\alpha / 1-\alpha} K_{t}
$$

The first expression after the equality sign, $\tau^{\alpha / 1-\alpha}$ is private marginal product of capital. By assumption, the consumers are expected to spend their income on goods and services and saves the surpluses. Note that : $Y_{t}-G_{t}=$ $C_{t}+\dot{K}$ and $Y_{t}=C_{t}+K_{t} \dot{+} G_{t}$, where

$G_{t}=\tau Y_{t}$. The aggregate budget constraint for the economy can now be expressed as:

$$
Y_{t}=C_{t}+\dot{K}+G_{t}
$$

Given the above budget constraint of the consumer, private capital is obtained by making $\dot{K}$ the subject of the formular and taking the derivative of $\dot{K}$ with respect to time. This gives the law of motion as expressed below:

$$
\frac{d K_{t}}{d_{t}}=\dot{K}=(1-\tau) Y_{t}-C_{t}
$$

The optimization problem now can be expressed as: Maximize Utility function defined by equation (3.1), subject to the budget constraint defined by equation (3.7). By substituting equation (3.5) into (3.7) gives:

$$
\dot{K}=(1-\tau) \tau^{\alpha / 1-\alpha} K_{t}-C_{t}
$$

Using the Hamiltonian, equation (3.8) yields:

$$
\frac{\dot{C}}{C}=\gamma=\frac{1}{\sigma}\left\{(1-\tau) \tau^{\alpha / 1-\alpha}-\rho\right\}
$$

Equation (3.9) represents the growth rate of output. A clear observation from equation (3.9) shows that imposition of tax has two conflicting effects on economic growth. First, imposition of tax drives growth directly because it enters negatively in the term within the parenthesis. Second, imposition of tax drives growth indirectly by increasing the private marginal product of capital. If the government is corrupt, it implies that not all the collected tax revenue are invested in public capital, rather, only a fraction of the revenue are invested in public capital, $G_{t}$, while the remaining fraction $\varepsilon_{t}$ represents the amount taken out of production machinery in the form of bribery. If we assume that the government has the following budget constraint :

$$
G_{t}=\tau Y_{t}-\varepsilon_{t}
$$

$G_{t}$ is the amount government spends on public capital. $\tau Y_{t}$ is tax revenue inflow, and $\varepsilon_{t}$ is aggregate bribes collected and diverted out of production machinery. There are two different permutations in which corruption may operate. 


\section{Permutation 1}

Let us first consider a situation where the amount of bribe collected by public officials is linear and directly proportional to tax revenues collected:

$$
\varepsilon_{t}=\mu \tau Y_{t}, 0<\mu<1
$$

$\mu$ represents corruption intensity. If corruption intensity rises, then the aggregate level of corruption is also expected to rise. No matter the amount the government decides to raise from taxes, there is always a constant amount programmed by the public offices to be diverted for personal enrichment. If we combine (3.10) and (3.11), corrupt government budget constraint becomes:

$$
G_{t}=(1-\mu) \tau Y_{t}
$$

$(1-\mu)$ represents the fraction of tax revenue used for public capital. The remaining fraction is consumed by rent-seekers, who are subset of the larger society. Substituting Equation (3.12) into equation (3.2) , we get :

$Y_{t}=[(1-\mu) \tau]^{\alpha / 1-\alpha} K_{t}$

Corruption intensity reduces the private marginal product of capital $[(1-\mu) \tau]^{\alpha / 1-\alpha}$ in equation (3.13). Bribe can be regarded as a windfall addition to consumer's income, and it impacted on consumption and savings level. Initially, bribe does not enter the decision set of the representative consumer. The consumer's disposable income is spent on consumption, while the excess is channelled to saving. From equation (3.10), expressing $\tau Y_{t}$ as the subject of formular, we have: $\tau Y_{t}=G_{t}+\varepsilon$.Aggregate output in the economy comprised of consumption, investment, effective public spending and bribes as shown in the equation below:

$$
Y_{t}=C_{t}+\dot{K}+G_{t}+\varepsilon_{t}
$$

If $\dot{K}$ is expressed as a dependent variable and taking note of equation

(3.13), capital evolves based on the law of motion as:

$$
\dot{K}=[1-\tau][(1-\mu) \tau]^{\alpha / 1-\alpha} K_{t}-C_{t}
$$

Equation (3.15) shows that corruption intensity has a greater influence on the overall level of corruption and it hinders the economy's drive at accumulating required capital for necessary growth. We observed that bribe constitute an unexpected addition (windfall) to consumer's income. Therefore, the utility function of the consumer is modified to capture the windfall gains from bribes and this is expressed as:

$$
U\left(c_{t}\right)+V\left(\varepsilon_{t}\right) \text {, where } U\left(c_{t}\right)=\frac{c_{t}^{1-\alpha}-1}{1-\sigma}
$$

The objective function now is equation (3.16), while the budget constraint is given by equation (3.15). The consumer maximizes equation (3.16) subject to equation (3.15). The growth rate is derived using the Hamiltonian and the first order condition without corruption, we have: 


$$
\gamma=\frac{1}{\sigma}\left\{[1-\tau][(1-\mu) \tau]^{\alpha / 1-\alpha}-\rho\right\}
$$

Equation (3.17) further shows that corruption intensity parameter, $\mu$, reduces the private marginal product of capital and this have implications on growth.

\section{Permutation 2}

If corruption intensity is introduced in a non-linear form, government's budget constraint is:

$$
G_{t}=\tau^{\theta} Y_{t}, \quad \theta \equiv 1+\mu
$$

Where $\mu(\mu \geq 0)$. If $\mu$ equals zero, it implies that government commits all revenue inflow from taxes to public projects. In most cases however, government display some form of corrupt behaviour by investing in low quality and welfare degrading projects that allows corrupt government bureaucrats to divert public funds for personal gains. This behaviour diminishes the efficiency of tax revenue on public projects. It therefore implies that some amount of public resources is wasted on unproductive expenditure by the corrupt bureaucrats. $\varepsilon_{t}=\left(1-\tau^{\mu}\right) \tau Y_{t}$ represents the amount wasted on unproductive expenditure. $\left(1-\tau^{\mu}\right)$ is the amount diverted from productive public spending. It should be noted that when corruption intensity increases, $\left(1-\tau^{\mu}\right)$ also increases but at a decreasing rate. The firm cannot influence both the government revenue decisions in regards to tax administration and corruption intensity parameter. They are exogenous to firm's production decision. The firm's production function can be expressed as:

$$
Y_{t}=[\tau]^{\frac{(1+\mu)^{\alpha}}{1-\alpha}} K_{t}
$$

In the presence of corruption, the private marginal product of capital falls, while in its absence, it rises. The private marginal product of capital in the presence of corruption is given by: $[\tau]^{\frac{(1+\mu)^{\alpha}}{1-\alpha}}$, while in its absence, it is given by: $[\tau]^{\frac{\alpha}{1-\alpha}}$. The private marginal product of capital in the presence of corruption is lower than the one obtained in its absence, and is given by the equation below:

$$
[\tau]^{\frac{(1+\mu)^{\alpha}}{1-\alpha}}<[\tau]^{\frac{\alpha}{1-\alpha}}
$$

We observed from the model that sustainable growth in output is stunted by corruption. If the factors driving corruption are not effectively checked, it would impact severely on the steady state output and economic growth. 


\section{Model Specification}

The empirical models for this study are derived from the theoretical framework discussed in section 3.0 above. In this study, the work of Barro (1990) and Bakare (2011) serves as the building framework of our model. We extend this model by including corruption among the factor inputs in the production technology. As specified by Barro (1990), aggregate output is expressed as:

$$
Y=A K^{\alpha} G_{Y}^{\beta}
$$

where: $\mathrm{Y}=$ Real output; $\mathrm{A}=$ Productivity index; $\mathrm{K}=$ Private capital; $\mathrm{G}_{\mathrm{Y}}=$ Public investment.

Corruption enters the model through public spending. $\beta$ represents the elasticity of output with respect to public investment, while $\alpha$ is the elasticity of output with respect to capital. $\beta$ is dependent on the level of corruption in the society. If corruption variable is included in the model, it would assist in ascertaining the actual amount of national resources eroded out of productive machinery towards corrupt activities. With this in mind, we therefore need to extend government expenditure function to capture corruption.

$$
\begin{aligned}
& G_{t}(\rho)=G^{*} e^{-\gamma \rho} \\
& \text { where } 0 \leq \rho \leq 1 \text {, and } \\
& G^{*}{ }_{t}=G_{0} e^{g t}
\end{aligned}
$$

The parameter $\rho$ represent corruption index. $\gamma$ gives the intensity of corruption in government spending. From equation (3.26), the growth rate of government spending $G_{t}^{*}$ is g. We assume that $\left(\frac{\partial G_{t}}{\partial \rho}\right)<0$, and $\left(\frac{\partial^{2} G_{t}}{\partial \rho^{2}}\right)>0$ . It is observed from equation (3.25) that if corruption term is not included, that is: if $(\rho)=0$ and $(\gamma=0)$, then $\mathrm{G}_{\mathrm{t}}^{*}=\mathrm{G}_{\mathrm{t}}$.

The modified version of Barro(1990) and Bakare(2011) model is stated in a functional form as:

$$
\operatorname{grth}_{t}=f\left(r m_{t}^{s}, \text { uemp }_{t}, \text { pubinv }_{t}, \text { cor }_{t}, \text { rcap }_{t}, \text { open }_{t}, \text { nsi }_{t}, \text { debt }_{t}\right)
$$

where :

grth = growth rate of real output;

$\mathrm{rm}^{\mathrm{s}}=$ money supply;

uemp = unemployment rate;

pubinv = share of domestic public investment in GDP;

cor = corruption perception index;

rcap = capital formation;

debt $=$ domestic debt;

open = openness to trade;

nsi $=$ national system of innovation;

$t=$ time 
The model can be expressed in a linear form as:

$$
\begin{aligned}
& \text { grth }_{t}=\omega_{0}+\omega_{1} \text { rm }^{s}{ }_{t}+\omega_{2} u e m p_{t}+\omega_{3} \text { pubinv }_{t}+\omega_{4} \text { cor }_{t}+\omega_{5} \text { rcap }_{t}+ \\
& \omega_{6} \text { open }_{t}+\omega_{7} n s i_{t}+\omega_{8} \text { debt }_{t}+\mu_{t}
\end{aligned}
$$

The parameters to be estimated are $\omega_{1}, \omega_{2}, \omega_{3}$, $\omega_{4}, \omega_{5}, \omega_{6}, \omega_{7}$ and $\omega_{8} . \mu_{t}=$ Error term.

We expect the parameters to be estimated to exhibit the following signs: $\omega_{1}>0, \omega_{2}<0, \omega_{3}>0, \omega_{4}<0, \omega_{5}>0, \omega_{6}>0, \omega_{7}>0, \omega_{8}<0$. Based on economic theory, the variables on the right hand side of equation (3.27) influences real growth in Nigeria.

\section{Data and Methodology}

The data used for this study are from many sources. Real money supply, unemployment rate, public investment, capital formation, openness to trade and domestic debt for 1980-2012 were obtained from the Central Bank of Nigeria Statistical Bulletin. Public investment data is proxied by government capital expenditure. Corruption variable were obtained from the various publications of Transparency International (TI), online. Other data were obtained from the World Development Indicator CD-ROM (2012). Three variables (growth rate of real output, money supply and capital formation) are transformed to natural logs. The logs of the variables were taken to reduce the variance level and also to linearize the variables in the analysis. Some preliminary tests were carried out on the data used for the analysis to ensure that our regression estimates were free from misleading results. The data employed in the study were estimated in phases starting with the unit root test, co-integration and estimation of error correction in the model (ECM). Specifically, the stationarity tests was conducted to ascertain the order of integration of the variables using the Augmented Dickey Fuller (ADF) and Phillip-Perron (PP) Tests respectively. The co-integration test seeks to examine whether there is longrun co-movement in the variables used in the model. The ECM, measures the short run dynamic adjustments towards long run equilibrium.

\section{Empirical Evidence \\ Unit Root Test}

The unit root tests revealed that all the variables are not stationary at the same level. While the growth rate of real output and money supply are stationary after second differencing, all other variables are stationary at first differencing. In order to determine how to model the short-run dynamics of real output growth, it is therefore important to carry out tests for cointegration. Table 3 show the unit root test results. 
Table 3: Unit Root Test Results

\begin{tabular}{|c|c|c|c|c|c|c|c|c|}
\hline Variable & & ADF & C.V 1\% & C.V 5\% & $\mathrm{PP}$ & C.V $1 \%$ & C.V 5\% & $\mathrm{O} / \mathrm{I}$ \\
\hline \multirow[t]{2}{*}{$\operatorname{grth}^{* *}$} & Level & -4.2946 & -4.3240 & -3.5806 & -4.2664 & -4.3240 & -3.5806 & \multirow[t]{2}{*}{$\mathrm{I}_{2}$} \\
\hline & 2nd Diff & -5.1346 & -4.4983 & -3.6584 & -5.6501 & -4.3561 & -3.5950 & \\
\hline \multirow[t]{2}{*}{$r m s^{* *}$} & Level & -1.2788 & -4.2846 & -3.5629 & -1.6160 & -4.2733 & -3.5578 & \multirow[t]{2}{*}{$\mathrm{I}_{2}$} \\
\hline & 2nd Diff & -7.9734 & -4.2967 & -3.5684 & -16.6091 & -4.2967 & -3.5684 & \\
\hline \multirow[t]{2}{*}{ uemp $p^{\text {*a }}$} & Level & -0.7157 & -4.2733 & -3.5578 & -0.5649 & -4.2733 & -3.5578 & \multirow[t]{2}{*}{$\mathrm{I}_{1}$} \\
\hline & $1^{\text {st }}$ Diff & -5.5559 & -4.2846 & -3.5629 & -5.5784 & -4.2846 & -3.5629 & \\
\hline \multirow[t]{2}{*}{ pubinv ${ }^{* *}$} & Level & -0.9517 & -4.2733 & -3.5578 & -1.5138 & -4.2733 & -3.5578 & \multirow[t]{2}{*}{$\mathrm{I}_{1}$} \\
\hline & $1^{\text {st }}$ Diff & -4.7670 & -4.2846 & -3.5629 & -4.7506 & -4.2846 & -3.5629 & \\
\hline \multirow[t]{2}{*}{ cor } & Level & -3.0029 & -4.2733 & -3.5578 & -3.0029 & -4.2733 & -3.5578 & \multirow[t]{2}{*}{$\mathrm{I}_{1}$} \\
\hline & $1^{\text {st }}$ Diff & -5.8171 & -4.2967 & -3.5684 & -12.9937 & -4.2846 & -3.5629 & \\
\hline \multirow[t]{2}{*}{ rcap } & Level & -0.1902 & -3.6537 & -2.9571 & -2.4255 & -4.2733 & -3.5578 & \multirow[t]{2}{*}{$\mathrm{I}_{1}$} \\
\hline & $1^{\text {st }}$ Diff & -4.7538 & -4.2846 & -3.5629 & -4.8095 & -4.2846 & -3.5629 & \\
\hline \multirow[t]{2}{*}{$d e b t^{*}$} & Level & -3.8356 & -4.2846 & -3.5629 & -3.4556 & -4.2733 & -3.5578 & \multirow[t]{2}{*}{$\mathrm{I}_{1}$} \\
\hline & $1^{\text {st }}$ Diff & -4.8510 & -4.2846 & -3.5629 & -4.8195 & -4.2846 & -3.5629 & \\
\hline \multirow[t]{2}{*}{ open } & Level & -3.5879 & -4.2733 & -3.5578 & -3.5879 & -4.2733 & -3.5578 & \multirow[t]{2}{*}{$\mathrm{I}_{1}$} \\
\hline & $1^{\text {st }}$ Diff & -8.4306 & -4.2846 & -3.5629 & -9.5543 & -4.2846 & -3.5629 & \\
\hline \multirow[t]{2}{*}{$n s i^{* * *}$} & Level & -1.2959 & -4.2846 & -3.5629 & -2.2659 & -4.2733 & -3.5578 & \multirow[t]{2}{*}{$\mathrm{I}_{1}$} \\
\hline & $1^{\text {st }}$ Diff & -8.6888 & -4.2846 & -3.5629 & -22.6937 & -4.2846 & -3.5629 & \\
\hline
\end{tabular}

Source: Computed from E-View 7.0 . Note $* *=$ trend and intercept.

$\mathrm{ADF}=$ ADF Test Statistics. C.V $=$ Critical Values. $\mathrm{PP}=$ Phillips Perron Test Statistics. O/ I $=$ Order of Integration.

\section{Cointegration Test}

There could be a situation when two or more time-series may not be stationary, it becomes imperative that we test whether there is a linear combination of them that are stationary. This phenomenon is referred to as test for cointegration. When there is cointegration among the variables, it implies that long-run relationship exist among the variables. However, the short-run dynamics of the model can be represented by an error correction mechanism (Engle and Granger 1987). We applied both the Engle-Granger Two-Step procedure and the Johansen Maximum Likelihood Methodology for the cointegration test. Table 4 show the results of the cointegration test using the Engle-Granger Two-Step procedure.

Table 4: Result of the Cointegration Test Using the Engle-Granger

\begin{tabular}{|c|c|c|c|c|c|}
\hline & \multirow{2}{*}{$\begin{array}{c}\text { Dickey } \\
\text { Fuller }\end{array}$} & \multicolumn{2}{|c|}{ Augmented- Dickey Fuller } & Phillips & Conclusion \\
\cline { 3 - 4 } & & One lag & Two lags & Perron & \\
\hline $\begin{array}{c}\text { Residual } \\
\text { from } \\
\text { the Static } \\
\begin{array}{c}\text { Long run } \\
\text { Model }\end{array}\end{array}$ & $-3.3230^{* *}$ & $-4.3743^{* *}$ & $-4.3943^{* *}$ & $-4.3561^{* *}$ & $\begin{array}{c}\text { There is } \\
\text { Cointegration }\end{array}$ \\
\hline
\end{tabular}

Note ** implies that the residual is stationary at the $1 \%$ level of significance Source: Computed from E-view 7.0

Table 5 presents the results of the cointegration test, using the Johansen methodology. We analyze the results based on the trace and the 
maximum eigen-value statistics. The trace statistic indicates 6 cointegrating equations at the $5 \%$ level of significance, while the max-eigen-value test indicates 5 cointegrating equations at the 5\% level. The cointegration test results are therefore uninformative about the number of cointegrating relations among the variables. However, Pesaran and Pesaran (1997) have pointed out that both the trace and the maximum-eigen value statistic give conflicting conclusions and decision about the number of cointegrating vectors should be based on economic theory or other available information. We therefore proceeded on the basis that at least, there is cointegration and then focused on the cointegrating relation that explains the growth rate of real output. This led to our normalization with respect to the growth of real output variable.

Table 5: The Johansen Cointegration Test

\begin{tabular}{ccccc}
\hline \hline $\begin{array}{c}\text { Hypothesized } \\
\text { No. of CE(s) }\end{array}$ & Eigenvalue & $\begin{array}{c}\text { Trace } \\
\text { Statistic }\end{array}$ & $\begin{array}{c}0.05 \\
\text { Critical Value }\end{array}$ & Prob.** \\
\hline \hline None * & 0.9939 & 407.6409 & 197.3709 & 0.0000 \\
At most $1 *$ & 0.8878 & 249.6510 & 159.5297 & 0.0000 \\
At most 2 & 0.7995 & 181.8353 & 125.6154 & 0.0000 \\
At most 3 & 0.7337 & 132.0244 & 95.75366 & 0.0000 \\
At most 4 & 0.7060 & 91.01080 & 69.81889 & 0.0004 \\
At most 5 & 0.5451 & 53.06563 & 47.85613 & 0.0150 \\
At most 6 & 0.4711 & 28.64885 & 29.79707 & 0.0674 \\
At most 7 & 0.2063 & 8.901039 & 15.49471 & 0.3746 \\
At most 8 & 0.0545 & 1.736639 & 3.841466 & 0.1876 \\
\hline \hline
\end{tabular}

Note: Trace test indicates 6 cointegrating eqn(s) at the 0.05 level, * denotes rejection of the hypothesis at the 0.05 level, ** MacKinnon-Haug-Michelis (1999) p-values.

\begin{tabular}{ccccc}
\hline \hline $\begin{array}{c}\text { Hypothesized } \\
\text { No. of CE(s) }\end{array}$ & Eigenvalue & $\begin{array}{c}\text { Max-Eigen } \\
\text { Statistic }\end{array}$ & $\begin{array}{c}0.05 \\
\text { Critical Value }\end{array}$ & Prob.** \\
\hline \hline None * & 0.9939 & 157.9899 & 58.43354 & 0.0000 \\
At most $1 *$ & 0.8878 & 67.81570 & 52.36261 & 0.0007 \\
At most 2 & 0.7995 & 49.81095 & 46.23142 & 0.0199 \\
At most 3 & 0.7337 & 41.01357 & 40.07757 & 0.0391 \\
At most 4 & 0.7060 & 37.94516 & 33.87687 & 0.0154 \\
At most 5 & 0.5451 & 24.41678 & 27.58434 & 0.1208 \\
At most 6 & 0.4711 & 19.74781 & 21.13162 & 0.0772 \\
At most 7 & 0.2063 & 7.164400 & 14.26460 & 0.4699 \\
At most 8 & 0.0545 & 1.736639 & 3.841466 & 0.1876 \\
\hline \hline
\end{tabular}

Max-eigenvalue test indicates 5 cointegrating eqn(s) at the 0.05 level, * denotes rejection of hypothesis at 0.05 level, ** MacKinnon-Haug-Michelis (1999) p-values

Source: Computed from E-view 7.0 


\section{The Short-run Dynamics of the Growth Rate of Real Output}

To the extent that the growth rate of real output and the regressors of the model are not stationary and cointegration is established, the appropriate mechanism for modelling the short run growth rate of real output for Nigeria is an error correction mechanism(ECM). The error correction model for the growth rate of real output was conducted. From the unit root test results, we observed that the growth rate of real output and real money supply were stationary at second difference, while unemployment rate, share of domestic public investment in GDP, corruption index, capital formation, domestic debt, openness to trade and national system of innovation were stationary at first difference. From the results, the ECM was estimated on the basis of the order of integration of the variables. However, the parsimonious ECM model produces the result presented in table 6. The parsimonious ECM was obtained by deletion of insignificant coefficients from the estimates (See the over parameterized model in table A1 of the appendix).

Table 6:Estimated Parsimonious Error Correction Model

\begin{tabular}{ccccc}
\hline \hline \multicolumn{2}{c}{ Dependent Variable: $\Delta$ GRTH } & & & \\
\hline \hline Variable & Coefficient & Std. Error & t-Statistic & Prob. \\
\hline \hline C & 0.0067 & 0.1581 & 0.0422 & 0.9669 \\
$\Delta$ RMS & 1.3956 & 1.4585 & 0.9568 & 0.0353 \\
$\Delta$ UEMP & -0.0342 & 0.0381 & -0.8980 & 0.0383 \\
$\Delta$ UEMP(-1) & -0.0649 & 0.0434 & -1.4956 & 0.0154 \\
$\Delta$ PUBINV(-1) & -1.0565 & 0.6866 & -1.5389 & 0.0143 \\
$\Delta$ COR & -0.4552 & 0.2136 & -2.1309 & 0.0490 \\
$\Delta$ RCAP(-1) & 0.4184 & 0.8928 & 0.4686 & 0.0646 \\
$\Delta$ DEBT & -1.5002 & 1.3841 & -1.0838 & 0.0295 \\
$\Delta$ OPEN & 2.9896 & 0.8328 & 3.5897 & 0.0025 \\
$\Delta$ OPEN(-1) & 0.7190 & 0.7327 & 0.9814 & 0.0341 \\
$\Delta$ NSI & 0.1997 & 0.0545 & 3.6665 & 0.0021 \\
$\Delta$ NSI(-1) & -0.0048 & 0.0576 & -0.0834 & 0.0935 \\
ECM(-1) & -1.3076 & 0.3274 & -3.9936 & 0.0503 \\
\hline \hline R-squared & 0.7623 & Mean dependent var & 0.0657 \\
Adjusted R-squared & 0.5839 & S.D. dependent var & 0.6031 \\
S.E. of regression & 0.3890 & Akaike info criterion & 1.2515 \\
Sum squared resid & 2.4214 & Schwarz criterion & 1.8644 \\
Log likelihood & -5.1464 & Hannan-Quinn criter. & 1.4434 \\
F-statistic & 4.2749 & Durbin-Watson stat & 1.7524 \\
Prob(F-statistic) & 0.0040 & \multicolumn{3}{c}{} \\
\hline \hline
\end{tabular}

Source: Computed from E-view 7.0

The growth rate of real output is influenced by changes in money supply, unemployment rate, share of domestic public investment in GDP, corruption, capital formation, domestic debt, openness to trade and national 
system of innovation. The ECM showed the expected negative sign and is significant at 5 per cent. The coefficients of money supply, lagged one period capital formation, openness to trade in lag one period and national system of innovation conformed to our expectation with positive signs. For real output to be increased and sustained, there should be a corresponding increase in the level of investment and innovation system. Trade openness positively influence output. This result conformed to the empirical findings of some studies which relate trade openness positively with output (Tybout 1996, Wong 2006, Haddad et.al 1996). Unemployment and domestic debt coefficients are negatively signed and conformed to our expectation. High unemployment rate discourages output. The argument put forward in this paper in respect of domestic debt is that it could retard the growth of output particularly if it is a "dead weight debt". If the debt contracted are not used for growth enhancing projects. The most interesting part of the result are the estimates of corruption and the share of domestic public investment in GDP (proxied by capital expenditure), reflecting a negative relationship with the real output growth. There were empirical regularities in the literatures confirming that corruption reduces the efficiency of investment and skewed the composition of government spending to less productive activities. In the long run, sustainable growth is impaired (see Brunetti 1997; Wei 1997; Alesina 1999 and Murphy 1993; Mo (2000), Pellegrini and Gerlaugh (2004) and Gyimah-Brempong and Camacho (2006). The negative sign attached to the coefficient of capital expenditure implies that the components of the expenditure are affected with corruption. Public officers prefer to commit state resources to big projects whose values are difficult to ascertain and at the same time the benefits accrued to individual hands through bribes and rent seeking to growth enhancing counterparts projects. Expenditure that falls into this category in Nigeria include: military equipment spending, construction of bridges and roads, infrastructure expenditure, etc. Corruption has a long run implication on the growth of output. It reduces the productivity of capital and labour inputs causing their respective marginal physical productivity to fall and at the same time affect their efficiency in terms of contribution to output.

The coefficient of determination measures the goodness of fit of the estimated model. The model is good in its prediction, and it explains about 76 per cent of the behaviour of real output growth in Nigeria. As expected, the error correction term ECM(-1) is of the expected negative sign and is significant in the growth function. The Johansen Maximum Likelihood was applied in order to get the determinants of the long run real output growth. The choice draws from the fact that the static long run model, which is obtained by the ordinary least squares, leads to biased and inconsistent estimates of the long run parameters. Table 7 show the normalized 
cointegrating equation of real output. Real output is driven by changes in money supply, reduction in unemployment and corruption rate, increase in the rate of investment, reduction in domestic debt, increase in trade openness and innovation system.

Table 7: Normalized Cointegrating Coefficients

Cointegrating equation(s) :Log likelihood 185.6687

\begin{tabular}{cccccccccc}
\hline \multicolumn{8}{c}{ Normalized Cointegrating Coefficients (Standard error in parentheses) } \\
Grth & $r m s$ & unemp & pubinv & cor & rcap & debt & open & $n s i$ \\
& 1.000 & 2.0276 & -0.1135 & -1.3879 & -2.0491 & 0.7471 & -3.9135 & 1.5075 \\
& & & 0.4473 & & & & \\
& & $(2.2322)$ & $(0.0065)$ & $(0.1510)$ & $(0.0631)$ & $(0.1773)$ & $(0.2389)$ & $(0.2356)$
\end{tabular}

\section{Conclusion and Recommendations}

Primarily, this paper has examined the relationship between output growth, corruption and public spending in the context of Nigerian economy over the period 1980 to 2011. Accordingly, various channels driving corruption and its implication on growth have also been taxonimized. However, a number of channels have been identified in the literature. These include: investment, human capital, political stability, trade openness, distortion in tax collection and public expenditure. Since this paper focused on corruption in public spending, the author therefore maintains the position that corruption reduces and diminishes the efficiency of public expenditure. The categories of public expenditure most affected by corruption were: public investment projects, procurement of goods and services, extra budgetary expenditure, "ghost" workers, dead pensioners, goods and services provided at below-market prices. This study provides evidence that corruption drives economic growth negatively and it also reduces the quality of public infrastructure and diverts the public spending to projects vulnerable to corruption.

A model of corruption was described to explain the behaviour of corrupt bureaucrats. This model was adapted from the work of Dissou and Yakautsava (2011) as the building framework. The model assumed that the economy comprised three agents, namely, consumer, firm and government. The three agents were interdependently connected together by economic activities in the economy. The behaviour of these agents determines the pervasiveness of corruption in the economy. Using Barro(1990) and Bakare(2011) specification, our result show that the estimates of money supply capital formation, openness to trade and national innovation system positively influence real output. Unemployment and domestic debt have negative influence on real output. Of most interest are the coefficients of corruption and the share of domestic public investment in GDP. Both 
coefficients negatively related with real output. This implies that public spending and corruption are inter related with one another. Corruption tends to enlarge the scope of public spending towards bribe enhancing projects that would benefit the bureaucrats.

The study further shows that in the long run, real output is driven by the growth in money supply, trade openness, national system of innovation and the rate of investment. In line with this explanation, corruption diminishes the quantum of public investment required to drive growth. Further findings from the result show that corruption affects negatively; the efficiency of capital and at the same time reduces its marginal productivity. This could have long run implications on output growth.

It is recommended that the Nigerian government should be more pragmatic in its efforts towards sensitizing the society against the problem of corruption and also set up a functional anti-corruption agency that would probe into corruption cases.

\section{References:}

Acemoglu, D. and Verdier, T. (1998). "Property rights, corruption and the allocation of talent: A general equilibrium approach", Economic Journal 108(450), 1381\{1403\}.

Aidt, T.S(2003). "Economic Analysis of Corruption; A Survey", Economic Journal, Vol. 113, No 491, pp F632-F652.

Alesina, A., and R. Wacziarg, (1998). "Openness, Country Size and Government". Journal of Public Economics, 69 (3), 305 - 321.

Azariadis, C, A. Lahiri (1997). "Do Rich Countries Choose Better Governments?", Working paper UCLA.

Bakare, A.S (2011)."The Crowding-out effect of corruption in Nigeria: An Empirical Study". Journal of Business Management and Economics, Vol.2(2). pp.059-068.

Bardhan, P., (1997). "Corruption and Development: A Review of Issues", Journal of Economic literature, Vol. xxxv, 1320-46.

Barro, R. J. (1991). "Economic growth in a cross section of countries", The Quarterly Journal of Economics 106(2), 407\{43\}.

Barro, R.J.(1990). "Government spending in a simple model of endogenous growth", Journal of political Economy, 98, S103-S125.

Brunetti,A.(1997). "Political variables in cross-country growth analysis”. Journal of Economic Surveys, 11(2), 163-190.

Coe, D, Helpman, E and Hoffmaister, A.(1997)."North-South R\&D Spillovers." Economic Journal 107(January):134-49.

De La Croix, D. and Delavallade, C. (2007), "Corruption et allocation optimale de l'investissement public", Revue conomique 58(3), 637\{647\}. 
De La Croix, D. and Doepke, M. (2009)."To segregate or to integrate: Education politics and democracy", Review of Economic Studies 76(2), $597\{628\}$.

Dissou,Y and Yakautsava,T.(2012),"Corruption, Growth, and Taxation". Theoretical Economics Letters, 2, 62-66. Downloadable at http://www.sciRP.org/journal/tel.

Ehrlich,I. and Lui, F. T. (1999)."Bureaucratic Corruption and Endogenous Economic Growth”. Journal of Political Economy,107(6:2), S270-S293.

Engle, R. F. and Granger, C. W. J.(1987), "Co-integration and errorcorrection: Representation, estimation and testing", Econometrica 55, 251276.

Gupta, S., de Mello, L. and Sharan, R. (2001), "Corruption and military spending", European Journal of Political Economy 17(4), 749\{777\}.

Haddad,M., de Melo,J. and Horton, B. (1996). "Morocco 1994-1989 Trade Liberalization, Exports and Industrial Performance" in Mark J. Roberts and J.R. Tybout (ed), Industrial Evolution in Developing countries, Oxford University Press.

Huntington, S. P. (1968). "Political Order in Changing Societies, New Haven, CT, Yale University Press.

La Porta, R., Lopez-de-Silanes, F., Shleifer, A., Vishny, R.W., (1999). "The Quality of Government. Journal of Law, Economics and Organization. 15 (1), $222-279$.

Leff,N.H.(1964). “Economic Development through Bureaucratic Corruption”. The American Behavioural Scientist, Vol.8 (2): 8-14.

Levine, R. and Renelt, D.(1992)."A sensitivity analysis of cross-country growth regressions", American Economic Review 82(4), 942\{63.

Li, H. Lixin, C. Xu and Zou, H.F. (2000). "Corruption, Income Distribution, and Growth”. Economics and Politics, 12 (2), 155-182

Mauro, P. (1995). "Corruption and growth", The Quarterly Journal of Economics 110(3), 681-712.

Mauro, P. (1997). "Why worry about corruption?", IMF Economic Issues 6, International Monetary Fund. The American Economic Review 64(3), pp.292-303.

Mauro, P. (1998). "Corruption and the composition of government expenditure", Journal of Public Economics 69(2), 263\{279\}.

Mo, P. H. (2001). "Corruption and Economic Growth”. Journal of Comparative Economics, 29(1), 66-79.

Pellegrini, L. and Gerlagh, R. (2004). "Corruption's effect on growth and its transmission channels", Kyklos57(3), 429-456.

Pesaran, H.M and Pesaran, B, (1997),. Working with Microfit 4.0, Oxford University Press, Ogun, O.D and Ogunlana,O.F. (2013).Towards Effective 
Corruption Combat: Modelling the effect of Corruption on Nigeria's Economic Growth. Unpublished paper.

Ogun, O. (2014): Corruption and Long-run Growth: A Framework. International Advances in Economic Research Vol. 20(2), pp. 245-246. ISBN N0.: 1083-0898.

Ogunlana, O.F (2015). Corruption and Economic Growth in Nigeria. An unpublished $\mathrm{PhD}$ Thesis in the Department of Economics, University of Ibadan, Nigeria.

Rodrik, D., (1998)."Why Do More Open Economies Have Bigger Governments?", Journal of Political Economy, 106(5), pp. 997-1034.

Rose-Ackerman, S.(1999)."Corruption and the Global Economy, Institute for International Economics, Washington, D. C., Chapter The Political Economy of Corruption, pp. 31-60.

Shleifer, A. and Vishny, R. W. (1993)."Corruption", The Quarterly Journal of Economics 108(3), 599-617.

Tanzi, V., and Davoodi, H. (1997).“Corruption, Public Investment and Growth”. IMF Working Paper .Vol. 97/139). Washington, D.C.: International Monetary Fund.

Tanzi,V.(1998)."Corruption around the world - causes, consequences, scope, and cures", IMF Working Papers 98/63, International Monetary Fund.

Treisman, D.,(2000)."The causes of corruption: a cross-national study". Journal of Public Economics, 76(3), 399-457.

Tybout, J.R.(1996)."Chile 1979-1986:Trade Liberalization and its Aftermath" in Mark J, Roberts and J.R Tybout (ed).Industrial Evolution in Developing countries. Oxford University Press.

Wacziarg, R.,(2001). "Measuring the Dynamic Gains from Trade". The World Bank Economic Review, 15(3), pp. 393 - 429.

Wong,S.A(2006)."Productivity and Trade Openness: Micro-Level Evidence from Manufacturing Industries in Equador (1997-2003)". Working Paper draft. Online Publication.

World Bank (2007),"Helping Developing Countries Combat Corruption: The Role of the World Bank, New York, Oxford University Press Crime in Nigeria” P39-51.

Available at: http://www.doingbusiness.org/ExploreEconomies/?economyid=143. Zellner, A., and H. Theil (1962)."Three-Stage Least Squares: Simultaneous Estimation of Simultaneous Equations". Econometrica, 30 (1), $54-78$. 


\section{APPENDIX}

Table A1 : The General / Overparameterized Error Correction Model Dependent Variable: $\Delta$ GRTH

\begin{tabular}{ccccc}
\hline \hline Variable & Coefficient & Std. Error & t-Statistic & Prob. \\
\hline \hline C & -0.107946 & 0.465226 & -0.232030 & 0.8549 \\
$\Delta$ GRTH(-1) & 0.078808 & 2.055878 & 0.038333 & 0.9756 \\
$\Delta$ GRTH(-2) & 0.889768 & 1.604807 & 0.554439 & 0.6777 \\
$\Delta$ RMS & 9.452925 & 2.457745 & 3.846179 & 0.0161 \\
$\Delta$ RMS(-1) & -10.06760 & 11.25325 & -0.894640 & 0.5354 \\
$\Delta$ RMS(-2) & -1.937640 & 1.071317 & -1.808652 & 0.3215 \\
$\Delta$ UEMP & -0.220055 & 0.212725 & -1.034461 & 0.0489 \\
$\Delta$ UEMP(-1) & 0.002703 & 0.133830 & 0.020199 & 0.0987 \\
$\Delta$ UEMP(-2) & 0.182365 & 0.185478 & 0.983214 & 0.5054 \\
$\Delta$ PUBINV & -1.335599 & 0.606150 & -2.203413 & 0.2712 \\
$\Delta$ PUBINV(-1) & 2.251544 & 4.759671 & 0.473046 & 0.0718 \\
$\Delta$ PUBINV(-2) & 1.303268 & 3.300856 & 0.394827 & 0.7606 \\
$\Delta$ COR & -0.419981 & 0.713553 & -0.588577 & 0.0661 \\
$\Delta$ COR(-1) & 1.132728 & 0.849721 & 1.333059 & 0.4097 \\
$\Delta$ COR(-2) & 0.611644 & 0.409779 & 1.492617 & 0.3758 \\
$\Delta$ RCAP & -1.070603 & 0.896666 & -1.193982 & 0.4439 \\
$\Delta$ RCAP(-1) & 3.424828 & 1.581958 & 2.164930 & 0.0275 \\
$\Delta$ RCAP(-2) & -1.506295 & 0.436224 & -3.453032 & 0.1795 \\
$\Delta$ DEBT & -7.400154 & 1.162211 & -6.367307 & 0.0992 \\
$\Delta$ DEBT(-1) & 6.361358 & 8.242796 & 0.771748 & 0.5816 \\
$\Delta$ DEBT(-2) & 5.051928 & 4.327935 & 1.167284 & 0.4510 \\
$\Delta$ OPEN & 0.750164 & 0.755865 & 0.992457 & 0.0502 \\
$\Delta$ OPEN(-1) & 0.808943 & 1.778848 & 0.454756 & 0.0728 \\
$\Delta$ OPEN(-2) & -0.433507 & 0.363876 & -1.191357 & 0.4445 \\
$\Delta$ NSI & 0.089376 & 0.031794 & 2.811055 & 0.0217 \\
$\Delta$ NSI(-1) & 0.110412 & 0.062530 & 1.765730 & 0.0328 \\
$\Delta$ NSI(-2) & 0.079243 & 0.082491 & 0.960625 & 0.5128 \\
ECM(-1) & -0.497660 & 1.110662 & -0.448076 & 0.7318 \\
\hline R-squared & 0.998724 & Mean dependent var & 0.065667 \\
Adjusted R-squared & 0.964271 & S.D. dependent var & 0.603112 \\
S.E. of regression & 0.114001 & Akaike info criterion & -2.941482 \\
Sum squared resid & 0.012996 & Schwarz criterion & -1.621335 \\
Log likelihood & 70.65150 & Hannan-Quinn criter. & -2.528029 \\
F-statistic & 28.98806 & Durbin-Watson stat & 2.308337 \\
Prob(F-statistic) & 0.145958 & & & \\
\hline \hline
\end{tabular}

Source: Computed from E-view 7.0 